\title{
THE AFFECTIVE AREOPAGITIC TRADITION IN MEDIEVAL NORTHERN EUROPE
}

\author{
WILLIAM J. WAINWRIGHT
}

University of Wisconsin - Milwaukee

\begin{abstract}
Recent students of mysticism have sharply distinguished monistic from theistic mysticism. The former is more or less identified with the empty consciousness experience and the latter with the love mysticism of such figures as Bernard of Clairvaux. I argue that a sharp distinction between the two is unwarranted. Western medieval mystics, for example, combined the apophatic theology of Dionysius the Areopagite with the erotic imagery of the mystical marriage. Their experiences were clearly theistic but integrally incorporated 'monistic moments'. I conclude by discussing Nelson Pike's claim that these monistic moments were themselves phenomenologically theistic.
\end{abstract}

The most influential typology of mysticism appearing in the years immediately following World War II was Walter Stace's. Stace argued that mystical consciousness is characterized by a 'sense of objectivity or reality', a 'feeling of blessedness, joy, happiness, satisfaction, etc., and a sense 'that what is apprehended is holy, or sacred, or divine'. It is also characterized by paradoxicality and alleged ineffability. The mystic offers descriptions of his experience which are contradictory if taken literally and claims that it cannot be adequately put into words (Stace 1960: 79). Mystical consciousness takes two forms. The extrovertive mystic perceives all things as one. Ordinary objects appear to be identical with each other and/or rooted in some unity which lies behind them. The world is also experienced as alive or conscious, or as rooted in life and consciousness. It is a 'living presence. The mind of the introvertive mystic, on the other hand, is empty of ordinary contents. Awareness of the phenomenal world vanishes, and space and time are no longer experienced. Ordinary mental activity is suspended and one's mind is 
stripped of abstract concepts and sensuous images. Having purified her consciousness, the introvertive mystic becomes aware of a 'One' with which she experiences union or identity. (Stace's introvertive mysticism appears to be indistinguishable from what others have called monistic mysticism and identified with pure consciousness - a state in which the mystic is conscious but conscious of nothing. $)^{1}$

While Stace's typology has been widely influential, it oversimplifies and thereby distorts the richness of spiritual experience. ${ }^{2}$ Two examples will make this clear. Buddhists cultivate an experience in which spatiotemporal reality is perceived as 'empty' - a conceptually unstructured flow of 'dharmas' (momentary physical or psychological events or states that resist further analysis). The object of the Buddhist's experience is not some permanent substance or force underlying things. It is the process of becoming itself - but viewed without attachment and without attempting to conceptualize it. This is not a form of introvertive mystical consciousness for the 'object' of the mystic's experience is the phenomenal world. But neither is the experience extrovertive in Stace's sense. Viewing things as a conceptually unstructured flow, and without attachment, appears to be phenomenologically distinct from perceiving their identity or seeing them as rooted in some larger life or unity.

The major difficulty with Stace's account, however, is its failure to mention love. This is extraordinary in view of the central role love plays in the accounts of both Eastern and Western theistic mystics. R. C. Zaehner hardly overstates the case when he concludes that Stace's 'failure to mention love can only be due to an obvious anti-Christian [or anti-theistic] bias reinforced by a massive ignorance of the whole tradition of love-mysticism within Hinduism itself' (Zaehner 1957: 200). The experiences that interest Stace are primarily knowledge experiences. Theistic mystical experiences on the other hand, are primarily love experiences, and love experiences and knowledge experiences are phenomenologically distinct. ${ }^{3}$

Zaehner distinguishes nature mysticism (or cosmic consciousness) and monistic (or soul) mysticism from theistic mysticism. Nature mysticism and monistic mysticism are roughly identical with Stace's

${ }^{1}$ Cf. Forman 1990: 3-49.

${ }^{2}$ In this respect it resembles the so-called 'perennial philosophy' of Aldous Huxley, and the neo-Vedanta of Rhadhakrishnan and Shri Aurobindo which is like it in many ways.

${ }^{3}$ On this point see Dhavamony 1971. 
extrovertive and introvertive mysticism. Theistic mysticism, on the other hand, cannot be accommodated within Stace's categories. It does involve introversion. The theistic mystic empties her mind of percepts, images, and all but a few of the most general and abstract concepts (such as 'being', 'presence', or 'love'). But unlike monistic experiences, theistic mystical consciousness has an object or content which is distinct from the self. (The experience is, in this sense, dualistic.) That object, however, is not identical with a part of the space-time world or with the space-time world as a whole. Yet what most clearly differentiates theistic mystical consciousness from other forms of mystical experience is that the nature of the relation between the mystic and the object of her experience is best indicated by the fact that she typically expresses it by employing the language of mutual love. For example, Christian mystics speak of spiritual marriage, and have interpreted the Song of Songs as an allegory of the relation between God and the soul. Bernard of Clairvaux referred to the highest union as the 'kiss of the mouth'. John of the Cross and some Sufi mystics wrote lyrics to express their experience which can be read as ordinary love poetry. Hymns and songs from the Hindu bhakti traditions provide yet other examples.

But Zaehner, too, is guilty of oversimplification. The uniqueness of Buddhist experience is ignored (Zaehner identifies it with cosmic consciousness), and theistic mysticism is more variegated than he recognizes. Zaehner focuses on introvertive modes of consciousness which are experienced as states of mutual love, noetic experiences ${ }^{4}$ in which the mystic not only loves but has an 'experimental [i.e., experiential] perception' of the beloved's love for the mystic. His account of theistic mysticism isn't entirely adequate, however.

For example, Zaehner pays insufficient attention to the integral role that the deployment of images plays in the life of many love mystics who highly prize imageless states. Henry Suso is not atypical. Not only was he a student of Meister Eckhart, he defended his master's teachings in The Little Book of Truth - although rather than quoting his mentor, ${ }^{5}$ Suso quotes from 'a supposedly unimpeachable source' whose ideas were 'very similar' to Eckhart's, namely, Dionysius the Areopagite. God, in Suso's view, is 'nameless, infinite, beyond the grasp of logical concepts. Since all names are incorrect when attributed to him, it is better to call him

${ }^{4}$ A noetic experience involves an apparent perception of some reality or truth.

${ }^{5}$ Whose views had become increasingly controversial. 
non-being or nothing.' ${ }^{6}$ Yet 'for Suso the use of images was not peripheral or secondary', as it largely was for Eckhart, 'but integral to attaining mystical consciousness' (McGinn 2005: 209). Letter 10, for example, insists that 'true perfection ... consists in the union of the highest powers of the soul with the origin of being in sublime contemplation ... But because the soul, given the weakness of our burdensome bodies, cannot continually cling to pure Good in a completely spiritual manner, it must have some concrete model to lead it back to this union, and the best thing for this that I know is the dear image of Jesus Christ' (Suso 1989: 359). And Suso's own spiritual practice involved 'a deeply emotional' imitation of the passion, 'a gazing on the bloody and suffering God-man' that leads to a suffering with the crucified Jesus (McGinn 2005: 213). ${ }^{78}$

Moreover, theistic mysticism is itself more variegated than Zaehner recognizes. For example, there is an introvertive state ('the prayer of simple regard') in which theistic mystics direct their will and affections towards God without experiencing his presence. In another, while God isn't 'experimentally' (or experientially) perceived, his presence is immediately inferred from the soul's sense of well-being, its advances in virtue, sensations of 'sweetness', and feelings of love. ${ }^{9}$ Orthodox mystics cultivate experiences in which the soul is invaded and permeated by a light which is identified with the divine energies. The experience is achieved by introversion but involves purified senses as well as a purified intellect (although the blind can have it). Other introvertive theistic

6 Tobin 1989: 28.

7 In spite of the necessity of their employment, however, Suso was acutely aware that even the best likenesses are always pitifully inadequate to express 'something that has no manner (of being), that is beyond all thinking and the human intellect'. For 'no matter what one compares it to, it is still a thousand times more unlike than like' (Suso 1989: 201).

${ }^{8}$ This is not peculiar to Suso. 'The role of Christ, both as Eternal Word, and especially as Incarnate ... is pervasive in [John] Tauler's teaching.' 'No one', Tauler said, 'can ever go beyond the image of our Lord Jesus Christ'. Tauler's concern is with ... 'Christ as the Light of the world', as 'the Door to the Father's Heart', as 'the Good Shepherd ... , and especially Christ on the Cross drawing all to himself' (McGinn 2005: 271). Nor is the importance of imagery unique to Christian theistic mystics. The great Shri Vaisnava theologian, Ramanuja, for example, describes visions of the 'supernal form' of Vishnu as described in scripture, radiant and resplendent, bearing his conch shell, sun disk, mace, and lotus, although he distinguishes them from direct experiences of God 'as he really is'. See Lipner 1986: 114-5; and Van Buitenen 1953: 132. The Shri Vaisnavas were Hindu monotheists who identified the one God with Vishnu.

${ }^{9}$ See, for example, Browne 1925; and, especially, Saudreau 1924. 
experiences appear to have a great deal of conceptual content and to be primarily knowledge rather than love experiences. Teresa of Avila's 'intellectual vision' of the Trinity is an example.

Most significant, perhaps, is Zaehner's comparative denigration of monistic mysticism. Zaehner argues that several Eastern and Western theistic mystics (Ruysbroeck, Ramanuja, and, possibly, Richard of St. Victor and al-Junayd) create the impression that they have themselves experienced two types of introvertive consciousness, that they know what monistic experiences are like because they have had them, but that there is a clearly distinct introvertive experience which is theistic in character which they have also experienced that is not to be confused with them and is clearly superior to them. ${ }^{10}$ The Roman Catholic theologian, Jacques Maritain, has implicitly suggested something similar, discussing experimental perceptions of God in Distinguish to Unite, or the Degrees of Knowledge, and 'soul mysticism' in 'The Natural Mystical Experience and the Void'. While the former involves a loving union with God, the latter consists in a non-conceptual apprehension of the soul's substantial existence or being through the medium of the act by which it empties itself of ordinary contents and suspends all normal mental activity. But while this distinction may be roughly correct, it pays insufficient attention to the fact that love mysticism sometimes incorporates monistic moments.

In Western Christendom, 'full union' and 'rapture' are often described as the penultimate goal of the Christian mystic's spiritual labours. ${ }^{11}$ In both experiences, God and the soul penetrate each other, are held in mutual embrace. ${ }^{12}$ And both sometimes culminate in 'union without distinction', a state in which the mystic momentarily ceases to distinguish between herself and God. Although the mystic believes that

${ }^{10}$ See van Ruysbroeck 1951: 155ff.; and Ramanuja 1969. Selections from Ramanuja's commentary are included in Appendix A of Zaehner 1969. For example, it would seem that sections $2: 53,2: 65,2: 69,2: 72,6: 20-23$, and 6:29-31 of Ramanuja's commentary describe monistic mysticism; that 6:47 describes a theistic experience; and that the introduction to 7 and 12:11-12 distinguishes between them. See also Richard of St. Victor 1957: 122-4. Portions of Junayd's Kitab al-Fana can be found in Zaehner 1969 (Appendix B, especially pp. 223-24). Cf . Zaehner's discussion of Junayd on pp. 135-53 of the same work.

${ }^{11}$ The ultimate goal of course is a permanent loving union with God.

12 Nelson Pike suggests that the distinction between full union and rapture is essentially one of 'place', of just 'where' the mutual penetration or embrace occurs. Full Union transpires 'within the soul. In Rapture the soul is transported 'out of itself'. See Pike 1992: 20, 35. 
'metaphysically there is duality', 'phenomenologically there is identity'. Nelson Pike has argued that union without distinction should 'not be thought of as a distinct kind of mystical experience', however. It is rather, 'the climax moment ... of Full Union and Rapture' (Pike 1992: 32, 37, 40). Although his interpretation may be controversial, a careful reading of Rhineland and a number of other Western Christian mystics supports it.

Consider Jan Ruysbroeck. ${ }^{13}$ In The Spiritual Espousals, Ruysbroeck 'speaks ... of a threefold division in the Christian life', namely, 'the active, [the] interior, and [the] contemplative lives' (Ruysbroeck 1985: 23). The Sparkling Stone adds a fourth - going 'forth [in love] to all in common' (Ruysbroeck 1985: 155). ${ }^{14}$

The active life includes repentance, penitence, obedience to 'God, the holy Church, and [one's] own conscience in all things', and - most importantly - intending 'God's glory in all [one's] works' (Ruysbroeck 1985: 156).${ }^{15}$ My primary focus in this paper, however, will be on the interior and contemplative lives.

In the second division of the Christian life (the interior),

God's interior stirring and touch makes us hunger and strive ... [And] the more there is of the touch, the more there is of the hunger and striving. This is a life of love at the highest level of [the soul's] activity ... God inclines himself toward us and we are thereby touched in love; our spirit by means of God's activity and amorous power, impels and inclines itself toward God, and thereby God is touched [my emphasis]. From these two movements there arises the struggle [or 'storm'] of love, for in this most profound meeting ... spirit is wounded by love ... [O]ur spirit and God's spirit cast a radiant light upon one another and each reveals to the other its countenance ... Each demands of the other what it is, and each

${ }^{13}$ Though I shall not discuss this here, Ruysbroeck is typical of the Western 'affective Dionysian' tradition that begins with John the Scot (Eriugena). See Addendum.

14 That the true mystic should go out in active love toward her neighbour is clearly implied in his earlier work as well. Thus the Espousals (Ruysbroeck 1985: 134-5) states that the true contemplative 'possesses his life in ... two ways, that is, in rest and in activity, and in each he is whole and undivided ... He goes toward God with fervent interior love ..., enters into God with his blissful inclination toward eternal rest, remains in God, and nevertheless goes out to creatures in virtue and righteousness through a love which is' bestowed upon all. It should also be noted that (as this passage implies), ideally all three (or four) lives should be lived concurrently.

15 Though Ruysbroeck adds that if it proves too difficult to 'keep God constantly before [one's] eyes, then at least [one] must intend and desire to live according to God's holy will' (Ruysbroeck 1985: 156). 
offers to the other and invites it to accept what it is. This makes these loving spirits lose themselves in one another. God's touch and his giving of himself, together with our striving in loving and our giving ourselves in return ... sets love on a firm foundation. (Ruysbroeck 1985: 114-15)

The interior life is an expression of 'active' love. But active love 'prepares [us] for ... an "essential love" that is "above [my emphasis] all activity" ... [Here] 'the spirit becomes love itself - that is essential love in the ground of its unity. ${ }^{16}$ As long as the spirit continues to burn in love (as it does in the second stage) 'it will be aware of distinction and difference between itself and God' when it examines itself. But when it is burnt up, 'it is onefold and without distinction and accordingly feels nothing but unity, for the measureless flame of God's love consumes and devours all that it can enfold in its own self' (Ruysbroeck 1985: 159). Here (at the contemplative stage) 'God's touch and our striving in love becomes a single love. Here a person become so possessed by love that he must forget both himself and God, and know nothing but love. In this way the spirit is consumed in the fire of love,... and itself becomes love above all' works and 'exercises of devotion' (Ruysbroeck 1985: 165). Or again, 'the lover [at the contemplative stage] is overcome and possessed by his Beloved in bare, essential love. Here the lover is lovingly immersed in his Beloved, so that each is entirely the other's, both in possession and in rest. There follows' what 'is called falling asleep in God ... where the spirit sinks away from itself without knowing how or where this takes place. Then there follows the ... last thing which can be expressed in words. It takes place when the spirit sees a darkness it cannot enter by means of the power of reason. In this state a person feels that he has died and lost his way and that he has become one with God, without difference. When he feels himself to be one with God, then God himself is his peace, his enjoyment, and his rest' (Ruysbroeck 1985: 183). Here God envelopes 'us in fathomless love', and 'makes us lose ourselves and flow forth into the wild darkness of the Godhead' where we 'are able to meet God with God and endlessly posses our eternal blessedness with him and in him' (Ruysbroeck 1985: 132). At this point it is no longer 'a matter of loving God with "our love" but rather of our allowing ourselves to be embraced in God's own love, which is in fact the Holy Spirit enfolding the contemplative in the same divine bond of love that unites Father and Son in the Spirit' (Ruysbroeck 1985: 30).

${ }^{16}$ Mommaers 1995: 163, my emphasis. The internal quotes are from Ruysbroeck's The Tabernacle. 
What are we to make of this? Ruysbroeck sometimes says things that sound heretical. For example: 'It is to be God with God, without intermediary or any element of otherness which could constitute an obstacle or impediment' (Ruysbroeck 1985: 146); 'The soul ceaselessly becomes the very resplendence which it receives' (Ruysbroeck 1985: 147) - 'a resplendence which he later identifies with the Son' (Ruysbroeck 1985: 20). Contemplatives 'are transformed and become one with the same light with which they see and are seen' (Ruysbroeck 1985: 150); they are 'made one with the Spirit of God' (Ruysbroeck 1985: 151). But these statements of identity are phenomenological, not ontological. The 'loving contemplative' temporarily loses awareness of his own separate identity. He 'neither sees nor feels in the ground of his being, in which he is at rest, anything other than an incomprehensible light' (Ruysbroeck 1985: 147). There is no ontological identity, however, and those 'who say that they themselves are Christ or God' are 'foolish and perverse' (Ruysbroeck 1985: 229-30).

Precisely how, though, should union 'without difference or distinction' be understood? Ruysbroeck describes it as 'an "eternal rest". Such rest ... is no longer in the contemplative's own deepest or "essential" being, however, 'but rather in God's being (wesen) which is the superessential being (overwesen) of all beings, including the contemplative herself' (Ruysbroeck 1985: 30, my emphases). 'There all exalted spirits are, in their superessential being, one enjoyment and one beatitude with God, without difference' (Ruysbroeck 1985: 266). ${ }^{17}$ Ruysbroeck's exemplarism helps explain this.

'Colossians 1: 15-16 where Christ is spoken of as the image of the invisible God ... in whom, through whom, and for whom all things have been created', and John 1: 1-4 which declares that 'all things came to be through him', and that 'all that came to be was alive with his life' provide the background for a doctrine of exemplarism that was developed by the Greek Fathers, Augustine, and by such later theologians as Anselm and Aquinas. Thomas Aquinas, for example, says that 'all things "are in God through their own intelligible natures, which in God is the same as the divine essence. Hence things that exist in God in that way are [my emphasis] the divine essence"'. Thus 'creatures have not only their created

${ }^{17}$ Note that Ruysbroeck says one in enjoyment and beatitude, not in ontological being. As he stated in The Mirror of Eternal Blessedness (Ruysbroeck 1985: 247), 'whenever I write that we are one with God, this is to be understood as a oneness in love and not in being or nature'. 
being in the temporal order but also an eternal being in God, a being identical with God himself' (Ruysbroeck 1985: 19). Aquinas's idea is this: The Logos or Word includes the eternal exemplars of every temporal being. But given the divine simplicity, and the fact that the Logos or Word is God, my eternal or 'intelligible being', too, is God. Ruysbroeck can thus say that 'in this divine image [our intelligible being] all creatures have an eternal life apart from themselves in their eternal Exemplar ... It is to this eternal image and likeness that the Holy Trinity has created us. God therefore wills that we go out from ourselves into this divine light, supernaturally pursuing this image which is our own life and possessing it with him both actively and blissfully in a state of eternal blessedness' (Ruysbroeck 1985: 149). For even though 'all creatures have this eternal life in God', contemplatives alone are able to "'behold" or experience it' (Ruysbroeck 1985: 20, my emphases). ${ }^{18}$

Yet whatever merits Ruysbroeck's metaphysico-theological explanation of union without distinction may have, an important question remains. Precisely how are we understand the experience (as distinguished from the explanation) of union without distinction? As we have seen, Pike thinks that it shouldn't 'be thought of as a distinct kind of mystical experience. It is rather, the climax moment - seldom achieved' of the experience of the contemplative's and God's mutual love (Pike 1992: 40).

There is no question, I think, but that Ruysbroeck's union without distinction is an integral part of an interconnected series of experiences which, when taken as a whole, are phenomenologically theistic. Considerably more controversial is Pike's claim that even though union without distinction is 'a monistic interval lacking subject-object structure as well as all sensory and sensory-like content', it, too, is 'phenomenologically theistic' (Pike 1992: 160, 162). Union, without distinction is 'empty'. Yet in virtue of its phenomenological ancestry, it can be described as, phenomenologically, 'an awareness of God-soul identity ... "God-soul identity" expresses a lack of experiential content. But ... it is a very specific lack', namely, a lack of the previously 'felt distinction between oneself and God' (Pike 1992: 164-65). Pike concludes

${ }^{18}$ In the Mirror, Ruysbroeck 'writes that the image of God which we have received in the depths of our being [namely, our eternal being or exemplar] is God's Son, in which we all live and are imaged forth. So intimate is this union that God's image "fills the mirror of our soul to overflowing so that no other light or image can enter there". But ... however intimate the union, there is nevertheless no strict identity. "The image is not the mirror, for God does not become a creature”.' (Ruysbroeck 1985: 27, 239) 
that whether a monistic experience is or isn't phenomenologically theistic is determined by its phenomenological history. Both Jains and Advaita Vedantins, for example, and some orthodox Christian mystics such as Ruysbroeck, have monistic experiences. But the Jain's and Advaitin's monistic experiences, on the one hand, and the Christian's monistic experiences, on the other, differ phenomenologically because their phenomenological ancestries ${ }^{19}$ are different.

There seem to me, though, only two ways in which the phenomenology of the Christian's monistic experience itself could differ from the phenomenology of the Jain's or Advaitin's. The first would be if an awareness of the climax moment's phenomenological ancestry were included in the climax moment. The second would be if the climax moment's phenomenological ancestry affected its feeling tone.

The first is a non-starter. If an awareness of union without distinction's phenomenological ancestry is part of it, then (pace Pike) it can't be phenomenologically identical with the monistic experiences of nontheistic mystics, for the latter don't include it. Moreover, if the climax moment did include such an awareness, it would have 'experiential content, ${ }^{20}$ and so (again contrary to Pike) not be empty.

19 And 'descendants', i.e., the spiritual experiences following or succeeding their monistic experiences.

${ }^{20}$ Pike employs two analogies to explain how union without distinction can be 'phenomenologically theistic' even though it is 'a monistic interval lacking subject-object structure as well as all sensory and sensory-like content' (Pike 1992: 160, 162). The first is this: Imagine two cases. In the first, 'I am sitting on a park bench reading a magazine when I am unexpectedly hit on the forehead with a baseball. Upon awakening' I describe my experience as 'stun-stars and fading consciousness ... I am later told what happened' and 'thereafter ... describe the experience as one of being hit on the head by a baseball'. In the second, I am playing second base, follow the ball as it leaves the plate, and move under it 'but ... I misjudge the catch and the ball hits me on the forehead. Again, I experience stunstars and fading consciousness. Upon awakening I do not have to be told what happened. I describe the experience as one of being hit on the head with a baseball'. 'Being hit with a baseball' describes something I perceive in the second case but not in the first. Because of its 'phenomenological ancestry', stun-stars and fading consciousness in case two is 'phenomenologically [an experience of] being hit with a ball'. While the two occurrences of stun-stars and fading consciousness are 'phenomenologically indistinguishable in that they involved the same kind of stun, the same kind of stars, [etc.] ..., they are phenomenologically distinct. "Hit with a baseball" describes the phenomenological content of the second experience. It does not do so with respect to the first' (Pike 1992: 162-63). The second analogy is this: Again imagine two cases. In the first, a spot of light is projected on a screen. In the second, two spots are projected and 'come closer and closer until they merge into a single spot' 'having the same spatial dimensions, brightness and 
Non-theistic and theistic monistic experiences might differ in feeling tone, however. It is possible, in other words, that while both experiences are devoid of intentional content, ${ }^{21}$ they differ with respect to their affective colouring, and that the difference in their affective colouring is a consequence of a difference in their phenomenological history. (Something like this difference in feeling tone does sometimes occur. The empty consciousness experience is typically joyful. But not always. J. A. Symonds had it and disliked it, a difference which can probably be accounted for by features of Symonds' personal history - for example, his inability to categorize it or assimilate it to the rest of his experience.) If the feeling tone of the theistic mystic's 'climax moment' is coloured by the feelings and emotions that are a feature of his love experiences, there would indeed be a phenomenological difference between his monistic experiences and the monistic experiences of his non-theistic counterparts although the difference would not be one of phenomenological content or object.

\section{ADDENDUM}

Dionysius's Celestial Hierarchy 'had ... noted that ... "seraphim" means "fire makers or carriers of warmth" while "cherubim" means "fullness of knowledge or carriers of wisdom" but he never identified the seraphic fire as the fire of love'. Both John the Scot ${ }^{22}$ and Hugh of St. Victor do. While John doesn't add 'any references to charity or love' to his translation of the Celestial Hierarchy, his commentary on it 'explains warmth as the warmth of charity, and fire as the ardour of love'. The motion of the Seraphim around the One is "super-burning" because the first hierarch of celestial

so on'. My awareness in the second case 'is not just a perception of unity but a perception of identity - not just a perception of one but of two that have become one ... With respect to this final moment of awareness ..., its phenomenological ancestry has survived as an ingredient in its phenomenological content' (Pike 1992: 164). The implication is clear. Union without distinction is 'empty': yet in virtue of its phenomenological ancestry, it can be described as, phenomenologically, 'an awareness of God-soul identity ... "God-soul identity" expresses a lack of experiential content. But ... it is a very specific lack', namely, a lack of the previously 'felt distinction between oneself and God' (Pike 1992: 164-65). Note, however, that both of the two analogues to the monistic moment (namely, union without distinction) in the theist's experience have phenomenological content while the so-called 'climax moment' of the theist's experience does not.

${ }^{21}$ That is, they lack an object phenomenologically distinct from their subject.

${ }^{22}$ The author of the first (and highly influential) Latin translation of the Dionysian corpus. 
powers burn above all who come after them in the love of the highest good', and Hugh of St. Victor agrees. ${ }^{23}$

Hugh's most important contribution to the Western affective Dionysian tradition, however, is his association of seraphic love with the bridal imagery of the Song of Songs. According to Hugh, the beloved of the Song 'is loved more than understood ... Love (dilectio) surpasses knowledge, and is greater than intelligence.' In the divine bridal chamber, humans and angels 'surround by desire what they do not penetrate by intellect' (Hugh). Because 'the bridal chamber of love is beyond the realm of knowing ... later authors [such as Bonaventure] can associate it with the darkness of unknowing, whether this be the cloud of Mt. Sinai or the dark night of the lovers' embrace' (Rorem 2009: 78-81).

For example, the anonymous author of the enormously influential Cloud of Unknowing says ${ }^{24}$ that 'by passing beyond yourself... you shall be carried up in your affection, and above your understanding, to the substance beyond all substances, the radiance of the divine darkness', and he exhorts the reader to 'enter by affection into the darkness' which Moses entered through 'exercising his affection alone' (Coolman 2009: 86-87). Similarly, 'the last of the great Victorines', Thomas Gallus, claimed that Moses was 'united to the intellectually unknown God through a union of love, which is affective or true cognition, a much better cognition than intellectual cognition' (Coolman 2009: 90f.). But 'for Gallus, while Dionysius offered a theoretical account of the soul's ascent to God' Solomon [in the Song of Songs] gives us the practice of the same mystical theology' (Coolman 2009: 91, first emphasis mine). The 'ecstatic climax' of the soul's ascent merges 'the love-sick night' of the Song of Songs, 'and the apophatic darkness of Dionysius' Moses' (Coolman 2009: 94). ${ }^{25}$

${ }^{23}$ There is 'a long tradition in Latin exegesis' which prepares for this. Gregory the Great, for example, claims that 'love itself is knowledge' (Coolman 2009: 89), and 'refers to the "Seraphim and their fiery love" as ... an exegetical commonplace' (although he never claims that Dionysius understood the Seraphim in this way) (Rorem 2009: 28-79).

${ }^{24}$ In his middle English paraphrase of the Mystical Theology, entitled Denis's Hidden Theology.

${ }^{25}$ It is worth noting that, for Gallus, while 'in the darkness of seraphic union [with God], ... the soul lacks "mental eyes", that is reason and understanding', it is able to touch and taste the beloved. 'This refreshment does not occur through a mirror, but through the experience of divine sweetness, because taste and touch are not accomplished through a mirror, ... though vision is'. And Gallus notes that while Scripture says that no one can see God and live, it does not say that no one can taste or touch God and live (Coolman 2009: 94-95). 
This affective Dionysian tradition not only infused the thought and practice of the great Rhineland mystics such as Suso, Tauler, and Ruysbroeck but also deeply influenced Teresa of Avila, John of the Cross and sixteenth-century Spanish mysticism more generally, ${ }^{26}$ as well as other western European mystics.

\section{BIBLIOGRAPHY}

Browne, Henry. 1925. Darkness or Light: An Essay in the Theory of Divine Contemplation (London and St. Louis: Herder)

Coolman, Boyd Taylor. 2009. 'The Medieval Affective Dionysian Tradition', in Sarah Coakley and Charles M. Stang (eds), Re-thinking Dionysius the Areopagite (Oxford: Wiley-Blackwell), pp. 85-102

Dhavamony, Mariasusai. 1971. Love of God According to Saiva Siddhanta (Oxford: Clarendon Press)

Forman, Robert K. C. 1990. 'Introduction: Mysticism, Constructivism, and Forgetting, in Robert K. C. Forman (ed.), The Problem of Pure Consciousness (New York and Oxford: Oxford University Press, 1990), pp. 3-49

Giron-Negron, Luis M. 2009. 'Dionysian Thought in Sixteenth-Century Spanish Mystical Theology', in Re-thinking Dionysius the Areopagite, op. cit., pp. 163-76

Lipner, Julius. 1986. The Face of Truth: A Study of Meaning and Metaphysics in the Vedantic Theology of Ramanuja (Albany: State University of New York Press)

Maritain, Jacques. 1959. Distinguish to Unite, or the Degrees of Knowledge, Translated from the 4th French ed. (New York: Charles Scribner's Sons), pp. 247-470

Maritain, Jacques. 1941. 'The Natural Mystical Experience and the Void', in Ransoming the Time, trans. by Harry Lorin Binnse (New York: Charles Scribner's Sons)

McGinn, Bernard M. 2005. The Harvest of Mysticism in Medieval Germany, vol. IV of The Presence of God: A History of Western Christian Mysticism (New York: Crossroad)

Mommaers, Paul. 1995. 'Mystically One with God', in Paul Mommaers and Jan Van Bragt, Mysticism, Buddhist and Christian: Encounters with Jan van Ruusbroec (New York: Crossroad)

Pike, Nelson. 1992. Mystic Union: An Essay in the Phenomenology of Mysticism (Ithaca, NY: Cornell University Press)

Stace, Walter T. 1960. Mysticism and Philosophy (Philadelphia and New York: J. B. Lippincott)

${ }^{26}$ See Giron-Negron 2009: 163-76. 
Ramanuja. 1969. The Gitabbashya of Ramanuja (Madras: Professor M. Rangacharya Memorial Trust, 1969)

Richard of St. Victor. 1957. Selected Writings on Contemplation, trans. by Clare Kirchberger (London: Faber and Faber)

Rorem, Paul. 'The Early Latin Dionysius: Eriugena and Hugh of St. Victor', in Re-thinking Dionysius the Areopagite, op. cit., pp. 71-84.

Ruysbroeck, John. 1951. The Adornment of the Spiritual Marriage, trans. and ed. by Evelyn Underhill (London: Faber and Faber)

Ruysbroeck, John. 1985. The Spiritual Espousals and Other Works, introduction and translation by James A. Wiseman (Mahwah, NJ: Paulist Press)

Saudreau, Auguste. 1924. The Mystical State, Its Nature and Phases, trans. by D. M. B. (London: Burns, Oates, and Washbourne)

Suso, Henry. 1989. The Exemplar, With Two German Sermons, trans., ed., and intro. by Frank Tobin (Mahwah, NJ: Paulist Press)

Tobin, Frank. 1989. 'Introduction', in Frank Tobin (ed. and trans.), Henry Suso: The Exemplar and Two German Sermons (Mahwah, NJ: Paulist Press), pp. 13-51

Van Buitenen, J. A. B. 1953. Ramanuja on the Bhagavadgita (The Hague: H. L. Smits)

Zaehner, R.C. 1957. Mysticism: Sacred and Profane (Oxford: The Clarendon Press)

Zaehner, R. C. 1969. Hindu and Muslim Mysticism (New York: Schocken Books) 